\title{
Evaluating the Radioprotective Efficacy of Dendrodoine Analog Against the Formation of Dicentric Aberration Frequency in Cultured Human Peripheral Blood Lymphocytes
}

\author{
K. B. Kalpana ${ }^{1}$, K. Thayalan ${ }^{2}$ and Venugopal P. Menon ${ }^{1, *}$ \\ ${ }^{I}$ Department of Biochemistry and Biotechnology, Faculty of Science, Annamalai University, Annamalainagar 608002, \\ Tamil Nadu, India \\ ${ }^{2}$ Dr. Kamakshi Memorial Hospital, Chennai, Tamil Nadu, India
}

\begin{abstract}
The present study was aimed to evaluate the protective efficacy of dendrodoine analog (DA), an aminothiazole derivative against the formation of radiation induced dicentric (DC) aberration frequency on cultured human peripheral blood lymphocytes. DA was chemically synthesized and the product thus obtained was purified using column chromatography packed with silica gel using chloroform as the solvent. The purity status of the final product was assessed employing high performance thin layer chromatography (HPTLC). The radioprotective efficacy of DA against the formation of DC aberration frequency was analyzed by pre-incubating human peripheral blood lymphocytes with the optimum concentration of DA, selected from our previous study, followed by exposure to different doses of radiation. The results indicated that there was a dose dependent increase in the formation of DC aberration frequency in the irradiated groups when compared to DA pre-treated groups which modulated the toxic effects of radiation by means of its effective DNA protective and antioxidant property.
\end{abstract}

Keywords: Aminothiazole derivative, Dendrodoine analog (DA), High performance thin layer chromatography (HPTLC), Dicentric aberration frequency, Antioxidant property.

\section{INTRODUCTION}

Cells react differently when subjected to radiation which leads to cellular damage, depending upon the dose of radiation and cell type. If the damage is mild and repairable, it will be handled by the cell's survival netwok but if the damage is extensive and irreparable, the cells will undergo apoptosis. Human peripheral lymphocytes represent a cell population which will be predominantly in a DNA presynthetic stage of the cell cycle (i.e. the G0 phase). Only $0.2 \%$ or less of the peripheral lymphocytes will be in the auto-synthetic cell cycle phase, and these probably come from the pool of large lymphoid cells representing stimulated lymphocytes or immature plasma cells. Cells from this group may give rise to the rare mitoses found occasionally in peripheral blood. Nowell [1] was the first to show that peripheral 'human leukocytes' can be stimulated by phytohaemagglutinin (PHA) to undergo in vitro mitoses, while Carstairs [2] showed that 'small lymphocytes' are the target cells for mitogenic initiation by PHA. In fact, human peripheral blood lymphocytes provide a convenient and readily available source of human material and are routinely used experimentally to assess the extent of cytogenetic damage induced by physical and chemical

*Address correspondence to this author at the Centre for Micronutrient Research (CMR), Department of Biochemistry and Biotechnology, Faculty of Science, Annamalai University, Annamalai Nagar-608002, Tamil Nadu, Índia; Tel: (91) 04144-238343; E-mail: biocmr@sify.com agents. Sax [3] developed his 'breakage first' hypothesis on the origin of X-ray induced chromosomal aberrations, followed by Revell [4] who proposed the alternative exchange hypothesis. In essence, Sax [3] has proposed that the damaged regions of separate chromosomes come into contact after induction of complete breaks and the ends move about and eventually combine to form exchanges. Alternatively, Revell [4] envisaged that the points of damage are not complete severances but are unstable sites which can interact with similar sites to form pairwise exchanges. There is a third possibility, introduced later by Chadwick and Leenhouts [5], of a lesion/non-lesion interaction whereby a damaged site, in the Revell sense, may interact with an undamaged chromosome to form an exchange. Several studies have employed X-rays to study their effects on radiation induced genetic damage [6-8]. Radiation at doses used in therapy depletes cellular alpha-tocopherol in normal cells, thereby increasing their risk of damage; animal studies show that whole-body exposure to X-ray irradiation decreases tissue concentrations of vitamins $\mathrm{C}$ and $\mathrm{E}$ [9]. The potential of antioxidants to reduce the cellular damage induced by ionizing radiation has been studied in animal models for more than 50 years. A number of dietary antioxidants have been reported to decrease free radical attack on biomolecules [10]. The application of antioxidant radioprotectors to various human exposure situations has not been extensive although it is generally accepted that endogenous antioxidants, such as cellular non-protein thiols and antioxidant enzymes, provide some degree of protection [11]. These antioxidants exhibit their radioprotective ability 
by either delaying or inhibiting cellular damage mainly through their free radical scavenging property [12]. These low-molecular-weight antioxidants can safely interact with free radicals and terminate the chain reaction before vital molecules are damaged. A wide range of antioxidant phytochemicals, including flavonoids, polyphenols, carotenoids, and organosulfur compounds, are antioxidants and are radioprotective in experimental systems [11,13].

The marine environment, covering $70 \%$ of the earth's surface and $95 \%$ of its tropical biosphere represents 34 of the 36 phyla of life and provides a fascinating variety of biodiversity exceeding that of the terrestrial environment. Partially responsible for the unique secondary metabolism of marine life are the ecological pressures in the marine ecosystem including significant competition for space, and a high level of symbiosis between different species [14]. The secondary metabolites of marine organisms possess a number of structural differences due to their biogenetic origin. A variety of marine sources including sponges, tunicates, red algae, acorn worms and symbiotic bacteria have been shown to generate indole alkaloids, which represent the largest number and most complicated of the marine alkaloids (1/4 of total alkaloids) [15]. Marine metabolites often possess complexities such as halogen substituents. Their structure elucidation, chemical modification, stereochemistry, synthesis and pharmacology have received a great deal of interdisciplinary attention from areas of research other than chemistry and include pharmacology, physiology and medicine. Thus compounds isolated or synthesized from marine organisms can be used to develop nutraceuticals with a medical-health benefit, including the prevention and treatment of disease.

Dendrodoine is a marine alkaloid extracted from the tunicate Dendrodoa grossularia [16]. It possesses a 1,2,4 thiadiazole unit, quite uncommon either in terrestrial or among marine natural products. Dendrodoine which belongs to the indole class of marine alkaloids has been reported to be cytotoxic to lymphoma cells L1210 in culture [16]. Grossularine 1 and 2, isolated from the tunicate Dendrodoa grossularia, possess cytotoxic properties, against L-1210 (ID ${ }_{50} 6$ and $4 \mu \mathrm{g} / \mathrm{mL}$, respectively), WiDr (colon) and MCF7 (breast) (both are $<0.01 \mu \mathrm{g} / \mathrm{mL}$ ) [17], and also appear to act as a mono intercalating agent of DNA. Though the synthesis of dendrodoine has been reported [18], further studies on it or its analog have not been reported. It was noted that the substitution of a thiazole ring in place of the thiadiazole ring in Fig. (1) would provide additional opportunities for introducing structural diversity. Thiazole moiety is present in a variety of natural and synthetic biomolecules. Aminothiazoles have been reported to possess a wide range of biological activities [19, 20]. The synthesis of complex natural products has been challenging and has led to the discovery of many novel reactions. The synthesis of several compounds has permitted the preparation of a large number of designated analogs. These studies have analyzed desirable modifications, which inevitably lead to the development of more suitable bioactive compounds. High performance thin layer chromatography (HPTLC) is a powerful analytical technique [21] due to its merits of reliability, simplicity, reproducibility and speed. Thus the present study was (a)

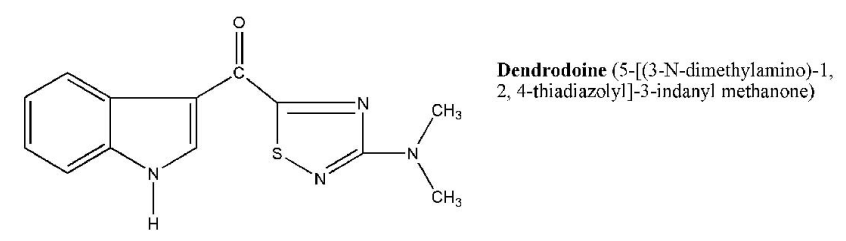

(b)

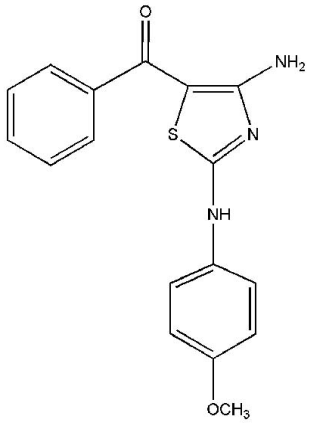

Dendrodoine analog (DA) yl-2- (4- methoxy phenylamino) thiazole]

Fig. (1). Molecular structure of dendrodoine and dendrodoine analog (DA).

undertaken initially to investigate the purity profile of the synthesized compound and then to analyze its DNA protecting ability against radiation induced damage on cultured human peripheral blood lymphocytes by performing dicentric (DC) aberration assay.

\section{MATERIALS AND METHODS}

\subsection{Chemicals}

Heat inactivated fetal calf serum (FCS), colchicine, histopaque-1077, chloroform (HPLC grade), methanol (HPLC grade) and HPTLC plates silica gel $60 \mathrm{~F} 254$ were obtained from E. Merck, Germany. Other chemicals like penicillin, streptomycin and L-glutamine were purchased from Himedia, Mumbai. Phytohemagglutinin M (PHA-M) was purchased from GIBCO-BRL, USA. All other chemicals and solvents were of analytical grade and were obtained from S.D. Fine chemicals, Mumbai.

\subsection{Synthesis of Dendrodoine Analog (DA) and Analyzing its Purity Profile Using High Performance Thin Layer Chromatography (HPTLC)}

DA was chemically synthesized in the lab as described by Rajasekaran et al., [22] and the product thus obtained was purified using column chromatography packed with silica gel using chloroform as the solvent. The purity check of the final product was confirmed using high performance thin layer chromatography (HPTLC). For this, 20 $\mu \mathrm{l}$ of the synthesized compound dissolved in methanol was applied onto HPTLC silica gel plates using CAMAG Linomat 5 instrument. Chloroform: Methanol (9:1) was used as the solvent system to develop the plate.

\subsection{HPTLC Operating Conditions}

Before operating HPTLC, the pressure in the nitrogen cylinder was ensured to be 4-6 bars. The application position (Y) was fixed at $10.0 \mathrm{~mm}$ and the position of the first track (X) was fixed at $15.0 \mathrm{~mm}$. The slit dimension was 
fixed as $6.00 \times 0.30 \mathrm{~mm}$, Micro. The band length was fixed as $8.0 \mathrm{~mm}$ and the applied band was then analyzed using CAMAG Scanner and the resulting peak was detected at 380 nm [23].

\subsection{Irradiation Protocol}

$6 \mathrm{MV}$ X-ray radiation source from the dual energy linear accelerator unit (Dr. Kamakshi Memorial hospital, Chennai, Tamil Nadu, India) was used for the irradiation purpose. Lymphocytes (with or without DA pre-treatment) were exposed to different doses of radiation, depending upon the requirement of the present study.

\subsection{Preparation of Dendrodoine Analog (DA) and Isolation of Lymphocytes}

DA $(1 \mathrm{mg} / \mathrm{ml})$ was dissolved in $0.2 \%$ dimethyl sulfoxide (DMSO) (w/v) and kept as stock solution. The stock solution was then diluted with sterile distilled water (milli-Q water) to arrive at the final effective concentration $(6 \mu \mathrm{g} / \mathrm{ml})$ selected from our previous study [24]. Blood samples were aseptically collected in heparinized sterile glass tubes from the median cubital vein of nonsmoking healthy individuals (22-25 years). Written consent was obtained from each one of them. Lymphocytes were isolated from blood using Ficoll-histopaque solution and cultured as described previously by Boyum (1968) [25]. PHA-M $(0.2 \mathrm{~mL})$ was added to the culture to initiate cell division. Cells were incubated at $37{ }^{\circ} \mathrm{C}$ in a humidified $5 \% \mathrm{CO}_{2}$ atmosphere. Typically, each culture consisted of an initial density of $1 \times$ $10^{6}$ cells in $2 \mathrm{ml}$ culture medium.

2.6. Culture set up for investigating the DNA protecting ability of DA by performing dicentric (DC) aberration assay

\begin{tabular}{|l|l|}
\hline $\begin{array}{l}\text { Sham } \\
\text { control }\end{array}$ & Culture received $0.2 \%$ DMSO as vehicle. \\
\hline $\begin{array}{l}\text { DA } \\
\text { control }\end{array}$ & DA $(6 \mu \mathrm{g} / \mathrm{ml})$ pre-treated lymphocytes. \\
\hline $\begin{array}{l}\text { Radiation } \\
\text { control }\end{array}$ & $\begin{array}{l}\text { The cultured lymphocytes were exposed to different }(1,2, \\
3 \text { and } 4 \text { Gy) doses of radiation. }\end{array}$ \\
\hline $\begin{array}{l}\text { DA + } \\
\text { radiation }\end{array}$ & $\begin{array}{l}\text { The culture of this group was treated with DA }(6 \mu \mathrm{g} / \mathrm{ml}) \\
\text { prior to exposure of different }(1,2,3 \text { and } 4 \mathrm{~Gy}) \text { doses of } \\
\text { radiation. }\end{array}$ \\
\hline
\end{tabular}

\subsection{Dicentric (DC) Aberration Assay and Scoring}

To $0.5 \mathrm{ml}$ of the lymphocyte culture (treated/untreated), $5 \mathrm{ml}$ culture medium (RPMI-1640) supplemented with $\mathrm{NaHCO}_{3}(7.5 \%$, w/v), $20 \%$ fetal calf serum, $200 \mathrm{mM} \mathrm{L}-$ glutamine, penicillin 100 units $/ \mathrm{ml}$ and streptomycin 100 $\mu \mathrm{g} / \mathrm{ml}$ were added. About $0.2 \mathrm{~mL}$ of PHA-M was added to the culture set up to initiate cell division. Colchicine was added at $67 \mathrm{~h}$ to block the cells at metaphase stage. The cells were then harvested at $72 \mathrm{~h}$, and were given hypotonic treatment for $10 \mathrm{~min}$ and transferred to a pre-cooled slide. The slides were stained with $10 \%$ Giemsa, mounted with DPX and examined under oil immersion to score DC aberration frequency [26]. The data are presented as the number of DC/100 cells.

\subsection{Statistical Analysis}

Statistical analysis was performed using one way analysis of variance (ANOVA) followed by Duncan's multiple range test (DMRT) by using statistical package of social science (SPSS) version 10.0 for windows. The values are given as mean \pm SD of six experiments in each group. $P$ values $\leq 0.05$ were considered as level of significance.

\section{RESULTS AND DISCUSSION}

\subsection{Checking the Purity Profile of DA Using HPTLC}

The structure of dendrodoine and dendrodoine analog (DA) is shown in Fig. (1). Since HPTLC is a powerful analytical technique, it was used to check the purity profile of the synthesized compound DA. This method described utilizes HPTLC silica gel 60 F 254 plates as the stationary phase. Different mobile phases containing different ratios of toluene, methanol, chloroform, acetone and acetonitrile were tested in order to obtain high resolution and reproducible peaks. Finally, the mobile phase chloroform: methanol (9:1, $\mathrm{v} / \mathrm{v}$ ) was selected as more appropriate for obtaining well defined and resolved peaks of DA. The \% area covered by peak 1 (Fig. 2), indicative of the compound DA was found to be 98.11 and the area covered by minor impurities was found to be 1.89. Thus the data obtained indicated the purity of DA to be greater than $98 \%$. The Rf values of the peak corresponding to DA is represented in Table 1. The molecular weight of the purified compound was found to be $325.38 \mathrm{~g}$.

\subsection{Dicentric Aberration Assay}

Previous work in many laboratories have demonstrated that chromosomal instability can be induced in a variety of mammalian cells by ionizing radiation of different radiation quality [27-31]. Chromosomal instability syndromes are also associated with an increased cancer risk [32] and there are reports stating that an increased rate of chromosomal aberrations indicated an increased risk for secondary cancer [33]. Thus after in vitro irradiation of cells, chromosomal aberrations [34] and repair of radiation-induced DNA damage (e.g., single- and double-strand breaks) [35] have been measured and the data obtained has been compared with different types of clinical side effects which might serve as a suitable approach to predict clinical radiation reactions. The frequency of DC aberration formation in human lymphocytes induced by different doses of radiation and in combination with DA is shown in Fig. (3). A dose dependent increase in the formation of total DC aberration frequencies was observed in the X-ray irradiated (1,2, 3 and $4 \mathrm{~Gy})$ groups when compared to the effective concentration of DA $(6 \mu \mathrm{g} / \mathrm{ml})$ pre-treated group. DA pre-treatment prior to the exposure of different doses of radiations (1, 2, 3 and $4 \mathrm{~Gy})$ showed a significant decrease in the formation of DC aberration frequencies and the protection offered by DA was approximately in the range of $80-85 \%$, which is the biological index for the detection of inhibiting potential of DA on cellular toxicity induced by X-ray radiation. Moreover, DA alone treated group did not induce any DC aberration frequencies in the cultured lymphocytes when compared to sham control group. In addition, our previous study also indicated that enhanced levels of lipid 


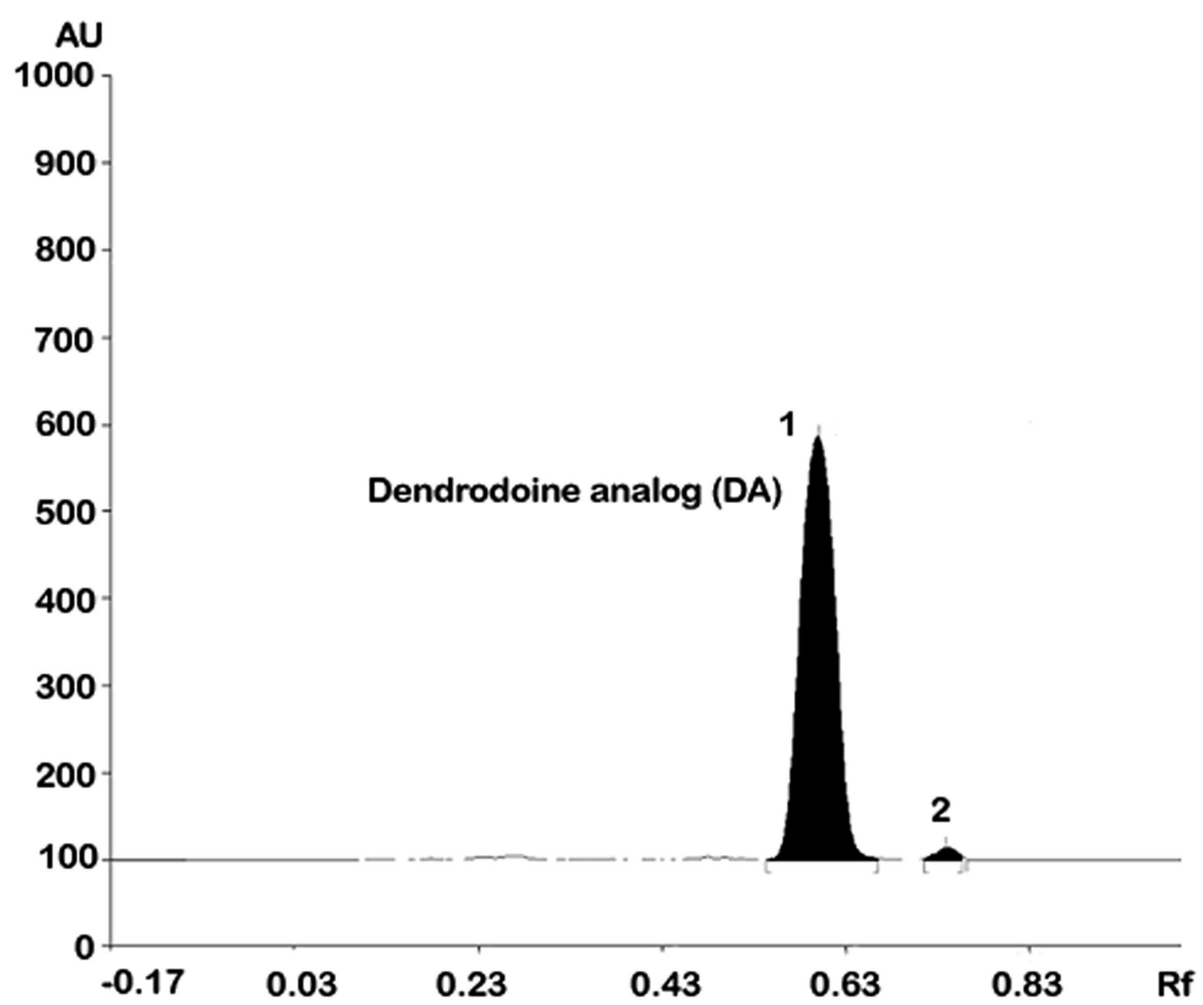

Fig. (2). Peak showing the purity profile of DA as analyzed using HPTLC.

Table 1. Purity Profile Data of Dendrodoine Analog (DA) as Analyzed by HPTLC

\begin{tabular}{|c|c|c|c|c|c|c|c|c|c|}
\hline Peak & Start Rf & Start Height & Max Rf & Max Height & $\operatorname{Max}(\%)$ & End Rf & End Height & Area & Area (\%) \\
\hline 1 & 0.55 & 0.8 & 0.60 & 487.8 & 97.01 & 0.67 & 2.3 & 12727.1 & 98.11 \\
\hline
\end{tabular}

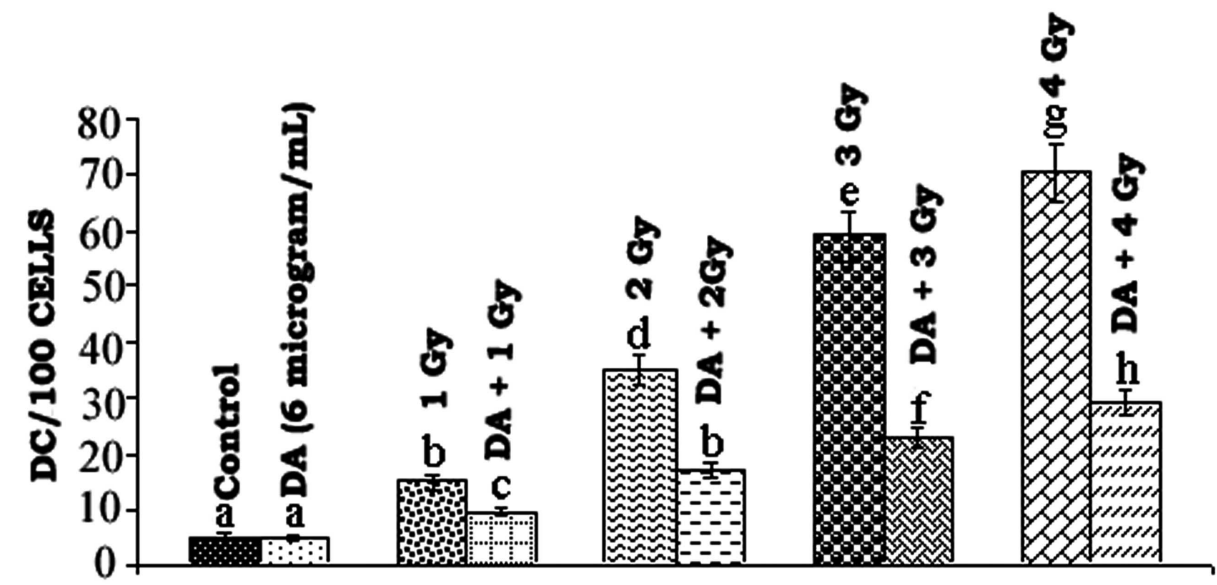

Fig. (3). Inhibitory effect of DA on the formation of DC aberration frequencies induced by different doses of radiation. Values are given as mean \pm SD of six experiments in each group. Values not sharing a common superscript differ significantly at $\mathrm{P} \leq 0.05$.

peroxidation induced by radiation are accompanied by a decrease in the activities of SOD, CAT and GPx in cultured human peripheral blood lymphocytes. However, treatment of lymphocytes with the effective concentration of DA prior to radiation exposure increased the antioxidant status and decreased the level of TBARS [24].
The exact mechanism by which DA develops the anticlastogenic potential is still unknown. But this may be due to the effective antioxidant potential of DA. As seen in Fig. (1), DA was found to possess antioxidant properties due to the presence of amino group at $\mathrm{C} 2, \mathrm{C} 4$ positions and a keto group at $\mathrm{C} 5$ position, which accept electrons from free 
radicals and neutralize them [36]. Previous reports have shown the in vivo antioxidant activity of 4-aminothiazoles and have also indicated that aminothiazoles possess antioxidant activity and inhibit lipid peroxidation [20]. In our previous study, we have also reported the antioxidant potential of DA and its protective effect against $\mathrm{H}_{2} \mathrm{O}_{2}$ induced oxidative damage on pBR322 DNA and RBC cellular membrane [37]. DA has also been reported to decrease the DNA damage by effectively scavenging the free radicals [38]. Moreover DA, besides its antioxidant property, may also form adduct with DNA or other macromolecules thereby preventing any loss of DNA activity. The DA- DNA complex may also be stable, preventing the complexed DNA from undergoing any mutation, resulting in decreased damage to DNA. Further studies are in progress to investigate the in vivo radioprotective efficacy of DA.

\section{CONCLUSION}

The result of the present study indicated that the purity of the synthesized compound DA was confirmed to be greater than $98 \%$ by HPTLC. The results on the DNA protecting ability of DA against radiation induced genetic damage on cultured human peripheral blood lymphocytes indicated that DA offered protection to DNA by effectively decreasing the formation of dicentric aberration frequency. Thus the purified compound DA can be used in the field of nutraceutical research due to its valuable antioxidant property with potential applications in health.

\section{CONFLICT OF INTEREST}

The authors display no conflict of interest.

\section{ACKNOWLEDGEMENT}

The authors gratefully acknowledge Dr. Kamakshi Memorial hospital, Chennai, Tamil nadu, India for providing the radiation facilities necessary to carry out our research work. K.B. Kalpana gratefully acknowledges the financial assistance awarded by Indian Council of Medical Research (ICMR), New Delhi, India in the form of Senior Research Fellowship.

\section{REFERENCES}

[1] Nowell PC. Phytohemagglutinin - An initiator of mitosis in cultures of normal human leukocytes. Cancer Res 1960; 20: 462-6.

[2] Carstairs K. The human small lymphocyte - Its possible pluripotential quality. Lancet 1962; 1(7234): 829-32.

[3] Sax K. Types and frequencies of chromosomal aberrations induced by X-rays. Cold Spring Harbor Symp Quant Biol 1941; 9: 93-103.

[4] Revell SH. A new hypothesis for chromatid exchanges, Radiobiology (Proc.Symp. Liège, 1954). London: Butterworths 1955; pp. 243-53.

[5] Chadwick KH, Leenhouts HP. The rejoining of DNA double-strand breaks and a model for the formation of chromosomal rearrangements. Int J Radiat Biol 1978; 33: 517-29.

[6] Attia AMM, Nabil GM, Frankenberg D, Frankenberg-Schwager M. Measurement of X-ray-induced DNA double-strand breaks at various stages of the cell cycle using the total fluorescence as a comet assay parameter. Radiat Phys Chem 2011; 80: 1178 -85.

[7] Ortenzi V, Meschini R, Berni A, Mancinelli P, Palitti F. Study on X-ray-induced apoptosis and chromosomal damage in G2 human lymphocytes in the presence of pifithrin- $\alpha$, an inhibitor of $\mathrm{p} 53$. Mutat Res 2011; 726: 29-35.

[8] Chua ML, Somaiah N, A'Hern R, et al. Residual DNA and chromosomal damage in ex vivo irradiated blood lymphocytes correlated with late normal tissue response to breast radiotherapy. Radiother Oncol 2011; 99: 362-6.
[9] Umegaku K, Aoki S, Esashi T. Whole body irradiation to mice decrease ascorbic acid concentrations in bone marrow: comparison with vitamin E. Free Radic Biol Med 1995; 19: 493-7.

[10] El-Habit OHM, Saada HN, Azab KHSH, Abdel Rahman M, ElMalah DF. Themodifying effect of beta-carotene on gamma radiation-induced elevation of oxidative reactions and genotoxicity in male rats. Mutat Res 2000; 466: 179-86.

[11] Weiss JF, Landauer MR. Protection against ionizing radiation by antioxidant nutrients and phytochemicals. Toxicology 2003; 189: 1-20.

[12] Halliwell B. How to characterize an antioxidant- An update. Biochem Soc Symp 1995; 61: 73-101.

[13] Borek C. Antioxidant health effects of aged garlic extract. J Nutr 2001; 131: 1010S-15S.

[14] Konig GM, Wright AD, Sticher O, Angerhofer CK, Pezzuto JM. Biological activities of selected marine natural products. Planta Medica 1994; 60: 532-7.

[15] Kobayashi J, Murayama T, Ishibashi M, et al. Hyrtiosins A and B, new indole alkaloids from the Okinawan marine sponge Hyrtios erecta. Tetrahedron 1990; 46: 7699-702.

[16] Heitz S, Durgeat M, Guyot M, Brassy C, Bachet B. Nouveau derive indolique du thiadiazole-1,2,4, isole d'un tunicier (Dendrodoa grossularia). Tetrahedron Lett 1980; 21: 1457-8.

[17] Moquin-Pattey C, Guyot M. Grossularine-1 and grossularine-2, cytotoxic $\alpha$-carbolines from the tunicate: Dendrodoa grossularia. Tetrahedron 1989; 45: 3445- 50.

[18] Hogan IT, Sainsbury M. Synthesis of 1, 2, 4- thiazole derivative, dendroine. Tetrahedron 1984; 40: 681-2.

[19] Ohkubo M, Kono A, Nakanishi I, Takasughi H. Studies on cerebral protective agents: synthesis of 2-aminothiazoles and 2-thiazolecarboxamides with antianoxic activity. Chem Pharm 1995; 43: 1497-504.

[20] Uchikawa O, Fukatsu $\mathrm{K}$, Suno $\mathrm{M}$, Aono $\mathrm{T}$, Doi T. In vivo biological activity of antioxidative aminothiazole derivatives. Chem Pharm Bull 1996; 44: 2070-7.

[21] Agarwal H, Kaul N, Paradkar AR, Mahadik KR. HPTLC method for guggulsterone: I. Quantitative determination of E- and Zguggulsterone in herbal extract and pharmaceutical dosage form. J Pharm Biomed Anal 2004; 36: 33-41.

[22] Rajasekaran KN, Nair KP, Jenardanan GC. Studies on the synthesis of 5-acyl-2, 4-diaminothiazoles from amidinothioureas. Synthesis 1987; 5: 353-5.

[23] Pappenberger G, Schulz-Gasch T, Kusznir E, Müller F, Hennig M. Structure-assisted discovery of an aminothiazole derivative as a lead molecule for inhibition of bacterial fatty-acid synthesis. Acta Crystallogr D Biol Crystallogr 2007; 63: 1208-16.

[24] Kalpana KB, Devipriya N, Thayalan K, Menon VP. Protection against X-ray radiation - induced cellular damage of human peripheral blood lymphocytes by an aminothiazole derivative of dendrodoine. Chem Biol Interact 2010; 186: 267-74.

[25] Boyum A. Isolation of mononuclear cells and granulocytes from human blood. J Clin Lab Invest Suppl 1968; 21: 77-89.

[26] Paul Salomon FD, Venkatachalam P, Jeevanram RK. A comparative study of synchronized and conventional methods on the micronucleus dose-response curve. Mutat Res 1997; 391: 91-8.

[27] Kadhim MA, MacDonald DA, Goodhead DT, Lorimore SA, Marsden SJ, Wright EG. Transmission of chromosomal instability after plutonium $\alpha$-particle irradiation. Nature 1992; 355: 738-40.

[28] Kadhim MA, Lorimore SA, Hepburn MD, Goodhead DT, Buckle VJ, Wright EG. Alpha particle-induced chromosomal instability in human bone marrow cells. Lancet 1994; 344: 987-8.

[29] Ponnaiya B, Cornfort MN, Ullrich RL. Induction of chromosomal instability in human mammary cells by neutrons and gamma rays. Radiat Res 1997; 147: 288-94.

[30] Holmberg K, Meijer AE, Auer G, Lambert B. Delayed chromosomal instability in human T-lymphocyte clones exposed to ionizing radiation. Int J Radiat Biol 1995; 68: 245-55.

[31] Marder BA, Morgan WF. Delayed chromosomal instability induced by DNA damage. Mol Cell Biol 1993; 13: 6667-77.

[32] Heim S, Johansson B, Mertens F. Constitutional chromosome instability and cancer risk. Mutat Res 1989; 221: 39-51.

[33] Boffetta $\mathrm{P}$, van der Hel O, Norppa $\mathrm{H}$, et al. Chromosomal aberrations and cancer risk: results of a cohort study from Central Europe. Am J Epidemiol 2007; 165: 36-43.

[34] Barber JBP, Burill W, Spreadborough AR, et al. Relationship between in vitro chromosomal radiosensitivity or peripheral blood 
lymphocytes and the expression of normal tissue damage following radiotherapy for breast cancer. Radiother Oncol 2000; 55: 179-86.

[35] Muller WU, Bauch T, Stuben G. Radiation sensitivity of lymphocytes from healthy individuals and cancer patients as measured by the comet assay. Radiat Environ Biophys 2001; 40: 83-9.

[36] Aruna K, Rukkumani R, Sureshvarma P, Menon VP. Role of an aminothiazole derivative on ethanol- and thermally oxidized sunflower oil-induced toxicity. Pol J Pharmacol 2004; 56: 233-40.
[37] Kalpana KB, Srinivasan M, Menon VP. Antioxidant potential of aminothiazole derivative and its protective effect on $\mathrm{H}(2) \mathrm{O}(2)$ induced oxidative damage on pBR322 DNA and RBC cellular membrane. Mol Cell Biochem 2008; 314: 95-103.

[38] De S, Adhikari S, Tilak-Jain J, Menon VP, Devasagayam TP. Antioxidant activity of an aminothiazole compound: possible mechanisms. Chem Biol Interact 2008; 173: 215-23.

Received: December 15, 2011

Revised: March 08, 2012

Accepted: March 09, 2012

(C) Kalpana et al.; Licensee Bentham Open.

This is an open access article licensed under the terms of the Creative Commons Attribution Non-Commercial License (http://creativecommons. org/licenses/ by-nc/3. 0/) which permits unrestricted, non-commercial use, distribution and reproduction in any medium, provided the work is properly cited. 